\title{
A survey of farmers knowledge and management practices adopted in cruciferous vegetables in Kanpur, Central Uttar Pradesh
}

NEELAM YADAV* AND NEERJA AGRAWAL

Department of Entomology, Chandra Shekhar Azad University of Agriculture and Technology, KANPUR (U.P.) INDIA

\section{ARITCLE INFO}

Received : 23.01 .2017

Revised : 12.09 .2017

Accepted : 23.09.2017

\section{KEY WORDS :}

Farmers, Practices, Cruciferous vegetables, Pesticides, IPM

*Corresponding author:

Email : neelu.amogh@gmail.com

\begin{abstract}
:
The survey was conducted during October 2015 to January 2016 among the farmers of four villages, viz., Bithoor, Pukharayan, Ghatampur and Kalyanpur in Kanpur region, Central Uttar Pradesh. The study revealed that maximum 75 per cent farmers were engaged in cultivation of cruciferous vegetables viz., cauliflower, cabbage, radish, turnip with other crops in Bithoor, Kalyanpur and Ghatampur whereas only 60 per cent were cultivating these crops in Pukhrayan. Out of total respondents of farmers from Kanpur districts, 82 per cent farmers were using chemical pesticides (mainly carabryl 50WP, Malathion 50EC, Cartap hydrochloride $0.5 \%$ and dichlorvos 100EC) whereas 16 per cent used indigenous methods ( chili powder spray, fly ash powder spray) along with chemical pesticides and 2 per cent were using biopesticides (azadirachtin, 5\% ). This paper explores potentials and limitations of different approaches to study pesticide use in agriculture from the farmers' perspective. In contrast to the reductionist and mono-disciplinary approaches often adopted, this paper calls for integrative methodological approaches to provide a realistic and thorough understanding of the farmers' perspective on pesticide in four sites of Kanpur.
\end{abstract}

How to view point the article : Yadav, Neelam and Agrawal, Neerja (2017). A survey of farmers knowledge and management practices adopted in cruciferous vegetables in Kanpur, Central Uttar Pradesh. Internat. J. Plant Protec., 10(2) : 434-437, DOI : 10.15740/HAS/IJPP/10.2/434-437. 